\title{
A Study of Layered Lithium Manganese Oxide Cathode Materials
}

\author{
Tom A. Eriksson and Marca M. Doeff \\ Materials Sciences Division, Lawrence Berkeley National Laboratory, University of \\ California at Berkeley, Berkeley, CA 94720, USA. \\ *Corresponding author: mmdoeff@lbl.gov
}

\begin{abstract}
Substituted layered sodium manganese oxide bronzes with the P2 structure were prepared by glycine-nitrate combustion synthesis. The $\mathrm{Na}$ in the as-prepared materials could be completely ion-exchanged for Li under mild conditions. All lithium manganese oxide compounds obtained after ion exchange have $\mathrm{O} 2$ stacking of the layers. Cyclic voltammetry and stepped potential experiments on lithium cells containing these materials show that the main redox reaction around $3.1 \mathrm{~V}$ is a diffusion-controlled process and is completely reversible. $\mathrm{O} 2-\mathrm{Li}_{0.6}\left[\mathrm{Al}_{0.1} \mathrm{Mn}_{0.85} \square_{0.05}\right] \mathrm{O}_{2}$ and $\mathrm{O} 2$ $\mathrm{Li}_{0.6}\left[\mathrm{Ni}_{0.1} \mathrm{Mn}_{0.85} \square_{0.05}\right] \mathrm{O}_{2}$ are particularly promising as cathode materials in lithium cells because of the high reversible discharge capacities $(180 \mathrm{mAh} / \mathrm{g})$.
\end{abstract}




\section{Introduction}

Novel materials for use as electrodes in Li-ion batteries have attracted much attention since Sony produced the first commercial Li-ion batteries in 1990. [1,2] Commercial Li-ion battery electrodes today contain expensive and hazardous compounds, like lithium cobalt or nickel, oxides or combinations of these. It is desirable to replace these with a manganese-based system, which is potentially cheaper and less toxic. However, the 3D spinel structures of lithium manganese oxides exhibit low capacities and poor cycling behavior. Recently layered lithium manganese oxides have been investigated in an attempt to improve these properties. [3,4] $\mathrm{LiMnO}_{2}$ with the $\alpha$ $\mathrm{NaMnO}_{2}$ structure, however, transforms into the more stable spinel structure upon electrochemical cycling. A non-stoichiometric layered sodium manganese oxide, $\mathrm{Na}_{0.7} \mathrm{MnO}_{2+\mathrm{y}}$, with a stacking sequence different from $\alpha-\mathrm{NaMnO}_{2}$, can be ion-exchanged to produce an electrode that should not transform into spinel upon cycling. [5] When directly synthesized with $\mathrm{Na}$ as the alkali metal ion the materials have a P2 structure, where $\mathrm{P}$ indicates a prismatic oxygen environment for the alkali metal ion and 2 indicates the number of $\mathrm{MO}_{2}$ sheets within the unit cell. Upon ion exchange, the stacking of the layers changes to $\mathrm{O} 2$ or $\mathrm{O} 6$ where the $\mathrm{Li}$ ion is in an octahedral site, or to $\mathrm{T} 2$ where the $\mathrm{Li}$ ion is in a tetrahedral site. [6] These materials showed promising electrochemical behavior, with a high initial discharge capacity. However, samples in the previous studies were incompletely exchanged, complicating interpretation of the cell cycling behavior.

Materials in the earlier studies had fairly large particle sizes (above $10 \mu \mathrm{m}$ ). [7] We have used glycine-nitrate combustion synthesis to produce the precursor P2 $\mathrm{Na}_{0.7} \mathrm{M}_{\mathrm{x}} \mathrm{Mn}_{1-\mathrm{x}} \mathrm{O}_{2}$ (where $\mathrm{M}$ is a metal substituent) compounds. [8,9] This method 
produces small particles that are more easily ion-exchanged under mild conditions than larger particles produced by conventional solid-state synthesis. The milder ion exchange has proven to be the most effective way to obtain stable cycling in layered lithium manganese oxide electrode materials. [10,11]

\section{Experimental}

Synthesis: The desired proportions of $\mathrm{NaNO}_{3}, 47.5 \% \mathrm{Mn}\left(\mathrm{NO}_{3}\right)_{2}$ in $\mathrm{HNO}_{3}$ and substituent metal-nitrate $\left(\mathrm{Ni}\left(\mathrm{NO}_{3}\right)_{3} \bullet 9 \mathrm{H}_{2} \mathrm{O}\right.$ or $\left.\mathrm{Al}\left(\mathrm{NO}_{3}\right)_{3} \bullet 9 \mathrm{H}_{2} \mathrm{O}\right)$ were mixed with glycine in the molar ratio 1:2 (glycine:nitrate) and diluted with de-ionized water. The temperature of the combustion reaction is determined by the glycine:nitrate ratio and was chosen to give $1300-1400^{\circ} \mathrm{C}$. [8] The solution was mixed with a magnetic stirrer over night, until all the nitrates were dissolved, and then slowly dripped into a metal beaker placed on a hot plate. The water evaporated and the nitrates reacted exothermically, with the glycine acting as fuel for the reaction. The as prepared powder was calcined at $800^{\circ} \mathrm{C}$ for $4 \mathrm{~h}$ to remove any organic residue and to obtain a homogenous material.

The materials were refluxed in a solution of $\mathrm{LiBr}$ in ethanol (9 fold excess of $\mathrm{Li}$ ) for $48 \mathrm{~h}$ at $80^{\circ} \mathrm{C}$, for the ion exchange.

Electrode preparation and cell assembly: The electrodes were prepared by thoroughly mixing $80 \mathrm{wt} \%$ active material with $6 \%$ carbon black (Shawinigan Black), $6 \%$ SFG-6 graphite (Timrex Timcal) and 8\% PVdF (from a 6\% NMP-solution) and extruding onto an aluminum-foil. The electrodes were allowed to dry over night at room temperature and for $24 \mathrm{~h}$ at $120^{\circ} \mathrm{C}$. Coin cells were assembled in a glove-box $(<1 \mathrm{ppm}$ $\mathrm{O}_{2} / \mathrm{H}_{2} \mathrm{O}$ ) using Cellgard 3401 as separator, ethylene-carbonate (EC)/dimethyl-carbonate 
$(\mathrm{DMC})+1 \mathrm{M} \mathrm{LiPF}_{6}$ electrolyte (Selectipur ${ }^{\circledR}$, Merck, Darmstadt, Germany), and Li-foil (Cyprus-Foote Mineral Co., Kings Mountain, NC) as the counter electrode.

Analysis: X-ray diffraction (XRD) was performed on a Siemens 5000D diffractometer, with monochromized $\mathrm{Cu}$ radiation $(\lambda=1.54 \AA)$. Scanning electron microscopy (SEM) was performed on a Microspec ISI-DS 130C microscope. An Arbin BT/HSP-2043 was used for the cyclic voltammetry (CV) experiments. Potential limits were set to 4.3 and 2.0 V. For the potential step measurements, a MacPile II (Bio-Logic, SA, Claix, France) was used. The elemental composition was determined by inductively coupled plasma (ICP) analysis (by Desert Analytics Laboratory, Tucson, AZ).

\section{Results \& Discussion}

The chemical analysis of the sodium-containing precursors yields a molar ratio of $0.6 \mathrm{Na}: 0.1 \mathrm{M}: 0.85 \mathrm{Mn}$ (where $\mathrm{M}=\mathrm{Al}$ or $\mathrm{Ni}$ ). The molar ratio on the transition metal site does not add up to one indicating that there are vacancies in the material. The composition can thus be written as $\mathrm{Na}_{0.6}\left[\mathrm{M}_{0.1} \mathrm{Mn}_{0.85} \square_{0.05}\right] \mathrm{O}_{2}$. After ion-exchange, ICP shows that the material has less than $7 \%$ sodium in the structure and the lithium content is about $\mathrm{x}=0.56$. No traces of the sodium P2 phase can be seen by XRD, implying that the sodium residue, seen with ICP, may be from sodium-containing impurities on the surface. By analogy to the sodium-containing precursors, we refer to the lithiated compounds as $\mathrm{Li}_{0.6}\left[\mathrm{Al}_{0.1} \mathrm{Mn}_{0.85} \square_{0.05}\right] \mathrm{O}_{2}$ or $\mathrm{Li}_{0.6}\left[\mathrm{Ni}_{0.1} \mathrm{Mn}_{0.85} \square_{0.05}\right] \mathrm{O}_{2}$ in this work.

From the XRD measurements, it can be concluded that the lithiated material has the $\mathrm{O} 2$ structure, with the peak assignments shown in Figure 1. No evidence of the T2 structure could be found in any samples. The T2 phase should appear as a split in the 
(110) peak at $66^{\circ}$ in 20. [6] A small peak matching the strongest reflection from the $\mathrm{O} 3$ structure (103) can be observed. This arises from exchange of a small $\mathrm{NaMnO}_{2}$ impurity present in the precursor material. $[12,13]$ As can be seen in the diffractograms, the peakshape and intensity varies between different reflections (Figure 1). For instance, the (002) and (110) reflections are very sharp and narrow with high intensities, while most of the other reflections are rather broad and not clearly defined. This is especially prominent for the (h0l) reflections. This indicates the presence of stacking faults, and makes Rietveld refinement of these patterns difficult to carry out with acceptable statistics. Because sliding of the $\mathrm{MnO}_{2}$ layers, which occurs during ion exchange and conversion of the $\mathrm{P} 2$ sodium form, can result in a number of different stackings, there is a high probability of ending up with a mix of e.g., O2, O6, and T2 stackings. [14] ${ }^{7} \mathrm{Li}$ MAS NMR experiments and transmission electron microscopy (TEM) analysis are more sensitive probes of local environments and are currently being undertaken to better understand the nature of the faults in these layered materials. [13]

The morphologies of the ion-exchanged powders were studied with SEM (Figure 2). It was found that they consist of small crystallites, about 1-4 $\mu \mathrm{m}$ across, which are slightly fused together from the calcination, into larger agglomerates of 15-30 $\mu \mathrm{m}$. These larger particles are very porous, allowing ready access of the electrolyte solution.

$\mathrm{Li} / \mathrm{Li}_{0.6}\left[\mathrm{Al}_{0.1} \mathrm{Mn}_{0.85} \square_{0.05}\right] \mathrm{O}_{2}$ and $\mathrm{Li} / \mathrm{Li}_{0.6}\left[\mathrm{Ni}_{0.1} \mathrm{Mn}_{0.85} \square_{0.05}\right] \mathrm{O}_{2}$ cells, as assembled, are in the partially discharged state and typically have open circuit potentials of about 3.1-3.3 V. Cells may either be charged or discharged initially. Cyclic voltammetry experiments on $\mathrm{Li} / \mathrm{Li}_{0.6}\left[\mathrm{Al}_{0.1} \mathrm{Mn}_{0.85} \square_{0.05}\right] \mathrm{O}_{2}$ cells show a highly reversible redox reaction (Figure 3A). Only one distinct peak can be observed in both scan directions and the 
difference in oxidation and reduction potential is $0.39 \mathrm{~V}$. This is unlike that of the differential capacity profiles previously reported for similar layered materials, which had spinel-like features, with main peaks near $3.0 \mathrm{~V}$ and one or two smaller peaks just below 4.0 V. $[15,16]$ We have previously observed that electrochemical properties of cathode materials derived from sodium manganese oxides vary considerably with the degree of exchange. [17] The presence of sodium ions between the layers and/or variations in the type and amount of stacking faults in the materials reported on earlier may account for the observed differences. Significantly, no changes in the cyclic voltammograms of our cells were observed after five consecutive sweeps, indicating that conversion to spinel or to other phases does not occur. This suggests that $\mathrm{Li}_{0.6}\left[\mathrm{Al}_{0.1} \mathrm{Mn}_{0.85} \square_{0.05}\right] \mathrm{O}_{2}$ should cycle stably in lithium or lithium ion configurations.

The $\mathrm{Li} / \mathrm{Li}_{0.6}\left[\mathrm{Ni}_{0.1} \mathrm{Mn}_{0.85} \square_{0.05}\right] \mathrm{O}_{2}$ cell (Figure 3B) also shows one peak in both scan directions, although it is somewhat broader than for the Al-substituted compound, and the potential difference between oxidation and reduction of $1.00 \mathrm{~V}$ indicates a more sluggish redox reaction .

Different sweep rates were used in order to investigate the nature of the redox reaction for $\mathrm{Li}_{0.6}\left[\mathrm{Al}_{0.1} \mathrm{Mn}_{0.85} \square_{0.05}\right] \mathrm{O}_{2}$ (Figure 4). For diffusion-controlled reactions, the peak current is typically proportional to the square root of the sweep rate, whereas those without diffusion steps, e.g. reactions of surface species, are directly proportional to the sweep rate. Reactions involving the solutes or solvents of the electrolyte, i.e. electrolyte decomposition, should be of the diffusion-controlled type, even if the product is solid and remains at the surface, (e.g. the solid electrolyte interface layer). It can be seen that there 
is a perfect linear relationship between the peak current and the square root of the sweep rate. Hence, the reactions in these electrode materials are diffusion controlled.

To obtain a pseudo open-circuit potential (OCP) profile, potential step experiments were performed. Differential capacity data obtained between 3.9 and $2.0 \mathrm{~V}$ was integrated to obtain the curves shown in Figure 5A and B. The potential profiles are gradually sloping and do not show a distinct plateau. The midpoint potential is about 3.0 $\mathrm{V}$ and the capacity obtained between these voltage limits is $180 \mathrm{mAh} / \mathrm{g}$ for both materials. $\quad \mathrm{Li}_{0.6}\left[\mathrm{Ni}_{0.1} \mathrm{Mn}_{0.85} \square_{0.05}\right] \mathrm{O}_{2}$ shows a larger polarization than $\mathrm{Li}_{0.6}\left[\mathrm{Al}_{0.1} \mathrm{Mn}_{0.85} \square_{0.05}\right] \mathrm{O}_{2}$, confirming the $\mathrm{CV}$ results that suggested slower kinetics in the Ni substituted compound. More information on the nature of the redox reaction can be obtained by examining the I vs. $t$ behavior for potential steps in the region of interest. For processes controlled by diffusion (e.g., a single phase reaction involving lithium insertion/de-insertion into a host), the current will increase or decrease proportionally with $\mathrm{t}^{-1 / 2}$ at short times $\left(\mathrm{t}<<\mathrm{L}^{2} / \mathrm{D}\right.$, where $\mathrm{L}$ is the diffusion pathlength and $\mathrm{D}$ is the chemical diffusion coefficient), according to the Cottrell equation. [18] This is seen for steps near $2.9 \mathrm{~V}$ in the discharge for the $\mathrm{Li}_{0.6}\left[\mathrm{Al}_{0.1} \mathrm{Mn}_{0.85} \square_{0.05}\right] \mathrm{O}_{2}$ cell (see inset in fig. $5 \mathrm{~A})$, suggesting that the reaction is single-phase in this region. Galvanostatic cycling experiments on cells containing substituted layered lithium manganese oxides are presently underway in this laboratory and will be discussed in subsequent publications.

\section{Conclusions}

O2 $\mathrm{Li}_{0.6}\left[\mathrm{Al}_{0.1} \mathrm{Mn}_{0.85} \square_{0.05}\right] \mathrm{O}_{2}$ and $\mathrm{Li}_{0.6}\left[\mathrm{Ni}_{0.1} \mathrm{Mn}_{0.85} \square_{0.05}\right] \mathrm{O}_{2}$ compounds may be used as cathodes in rechargeable lithium cells. Fully-exchanged materials prepared from 
P2 sodium manganese oxides precursors obtained via glycine-nitrate combustion synthesis appear to cycle stably and have attractive electrochemical properties, giving up to $180 \mathrm{mAh} / \mathrm{g}$ at an average potential of $3.0 \mathrm{~V}$.

\section{Acknowledgments}

This work was supported by the Assistant Secretary for Energy Efficiency and Renewable Energy, Office of FreedomCAR and Vehicle Technologies of the U.S. Department of Energy under Contract No. DE-AC03-76SF00098. T.A. Eriksson was funded by The Hans Werthen Foundation and The American-Scandinavian Foundation. 


\section{References}

[1] M. Winter, J.O. Besenhard, M.E. Spahr, P. Novak, Adv. Mater., 10 (1998) 725.

[2] J.M. Tarascon, M. Armand, Nature, 414 (2001) 359.

[3] A.R. Armstrong, P.G. Bruce, Nature, 381 (1996) 499.

[4] B. Ammundsen, J. Paulsen, Adv. Mater., 13 (2001) 943.

[5] J.M. Paulsen, C.L. Thomas, J.R. Dahn, J. Electrochem. Soc., 146 (1999) 3560.

[6] J.M. Paulsen, R.A. Donaberger, J.R. Dahn, Chem. Mater., 12 (2000) 2257.

[7] J.M. Paulsen, D. Larcher, and J.R. Dahn, J. Electrochem, Soc., 147 (2000) 2862.

[8] L.A. Chick, L.R. Pederson, G.D. Maupin, J.L. Bates, L.E. Thomas, G.J. Exarhos, Mater. Letters, 10 (1990) 6.

[9] L.R. Pederson, L.A. Chick, G.J. Exarhos, US Patent 5114 702, (1992).

[10] A.D. Robertson, A.R. Armstrong, P.G. Bruce, J. Chem. Soc., Chem. Commun., (2000) 1997.

[11] A.D. Robertson, A.R. Armstrong, P.G. Bruce, Chem. Mater., 13 (2001) 2380.

[12] J.-P. Parant, R. Olazcuaga, M. Devalette, C. Fouassier, and P. Hagenmuller, J. Solid State Chem., 3 (1971) 1.

[13] T.A. Eriksson, Y.J. Lee, J.A. Reimer, E.J. Cairns, and M.M. Doeff, submitted to Chem. Mater.

[14] Z. Lu and J.R. Dahn, Chem. Mater., 13 (2001) 2078.

[15] J.M. Paulsen, C.L. Thomas, and J.R. Dahn, J. Electrochem. Soc., 147 (2000) 861.

[16] J.M. Paulsen and J.R. Dahn, J. Electrochem. Soc., 147 (2000) 2478.

[17] M. M. Doeff, T. J. Richardson, and L. Kepley, J. Electrochem. Soc. 143 (1996) 2507). 
[18] C. J. Wen, B. A. Boukamp, and R. A. Huggins, J. Electrochem. Soc. 126 (1979) 2258. 


\section{Figure Captions}

Figure 1. XRD patterns of $\mathrm{Li}_{0.6}\left[\mathrm{Al}_{0.1} \mathrm{Mn}_{0.85} \square_{0.05}\right] \mathrm{O}_{2}$ and $\mathrm{Li}_{0.6}\left[\mathrm{Ni}_{0.1} \mathrm{Mn}_{0.85} \square_{0.05}\right] \mathrm{O}_{2}$. The theoretical XRD patterns of $\mathrm{O} 3$ and $\mathrm{O} 2$ structures are also included.

Figure 2. SEM image of $\mathrm{Li}_{0.6}\left[\mathrm{Ni}_{0.1} \mathrm{Mn}_{0.85} \square_{0.05}\right] \mathrm{O}_{2}$.

Figure 3. Cyclic voltammetry experiments at a sweep rate of $0.05 \mathrm{mV} / \mathrm{s}$. A) 3 cycles on a charged $\mathrm{Li} / \mathrm{Li}_{0.6}\left[\mathrm{Al}_{0.1} \mathrm{Mn}_{0.85} \square_{0.05}\right] \mathrm{O}_{2}$ cell, starting with the reduction sweep. B) $4^{\text {th }}$ cycle on a charged $\mathrm{Li} / \mathrm{Li}_{0.6}\left[\mathrm{Ni}_{0.1} \mathrm{Mn}_{0.85} \square_{0.05}\right] \mathrm{O}_{2}$ cell.

Figure 4. Cyclic voltammetry experiments on a $\mathrm{Li} / \mathrm{Li}_{0.6}\left[\mathrm{Al}_{0.1} \mathrm{Mn}_{0.85} \square_{0.05}\right] \mathrm{O}_{2}$ cell, at different sweep rates. Inset: the square-root of the sweep rate plotted against the peak current.

Figure 5. Potential profiles from potential step measurements. A new step was taken every 4 h or when $\mathrm{I}<0.1 \mu \mathrm{A}$. A). $\mathrm{Li} / \mathrm{Li}_{0.6}\left[\mathrm{Al}_{0.1} \mathrm{Mn}_{0.85} \square_{0.05}\right] \mathrm{O}_{2}$ cell. Inset: the I$\mathrm{t}$ profile for one potential step at $2.90 \mathrm{~V}$. The dotted line in the inset is a simulation of the Cottrell equation, offset for clarity. B). $\mathrm{Li} / \mathrm{Li}_{0.6}\left[\mathrm{Ni}_{0.1} \mathrm{Mn}_{0.85} \square_{0.05}\right] \mathrm{O}_{2}$ cell. 
Figure 1.

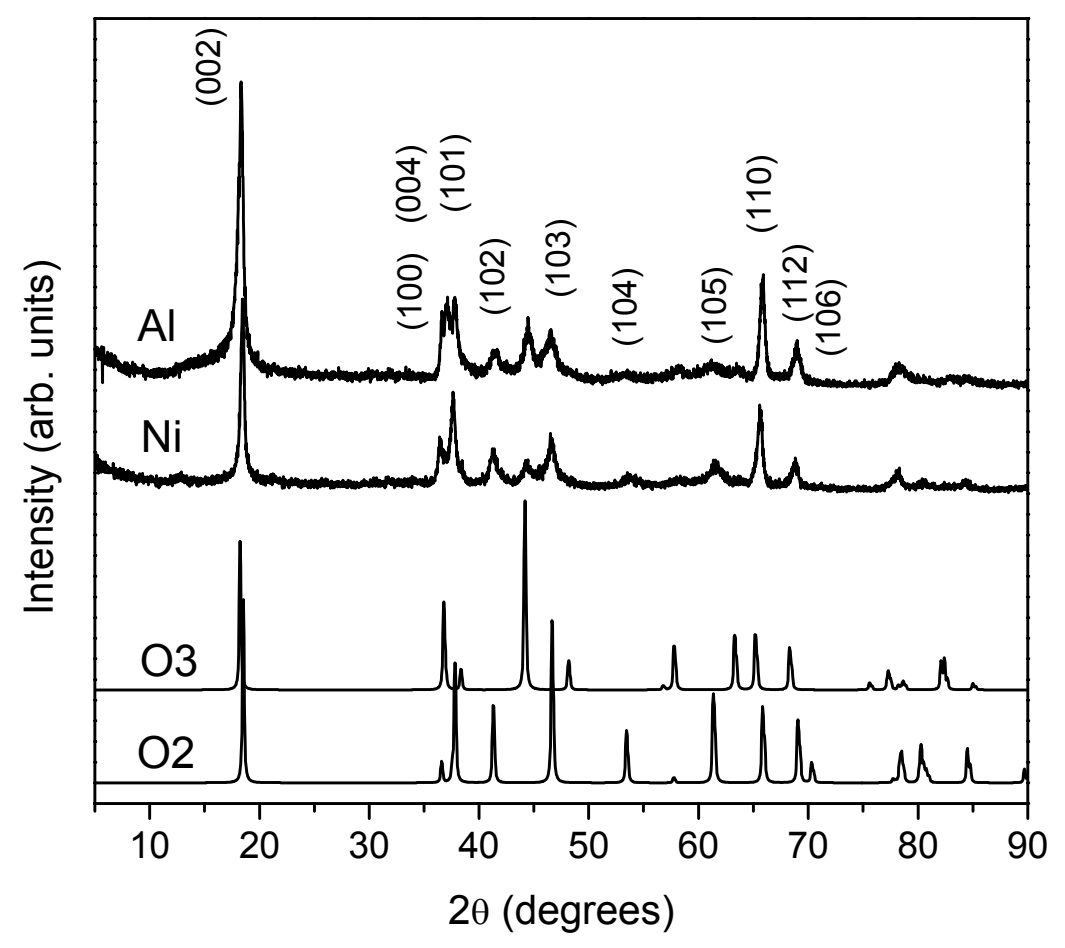


Figure 2.

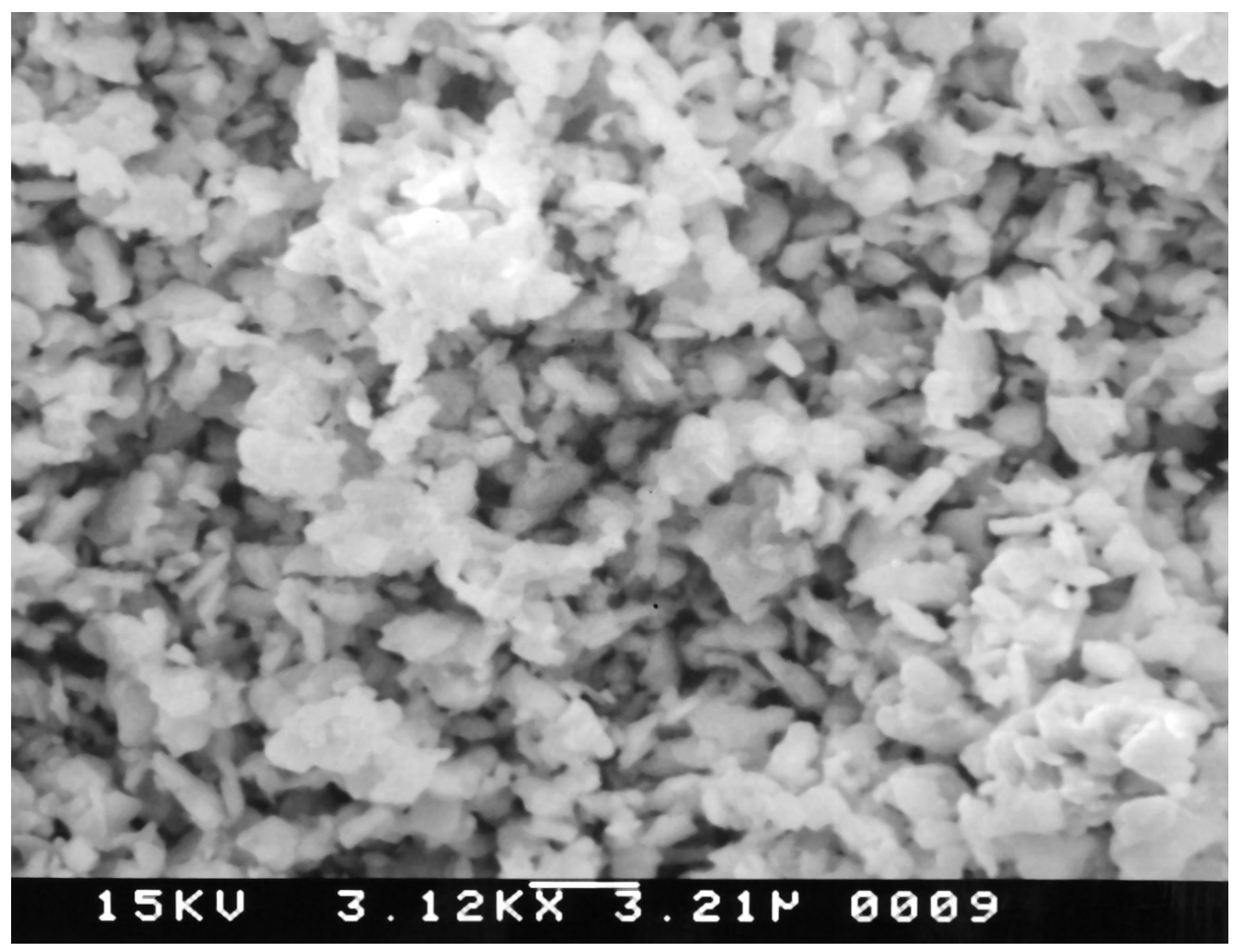


Figure 3.
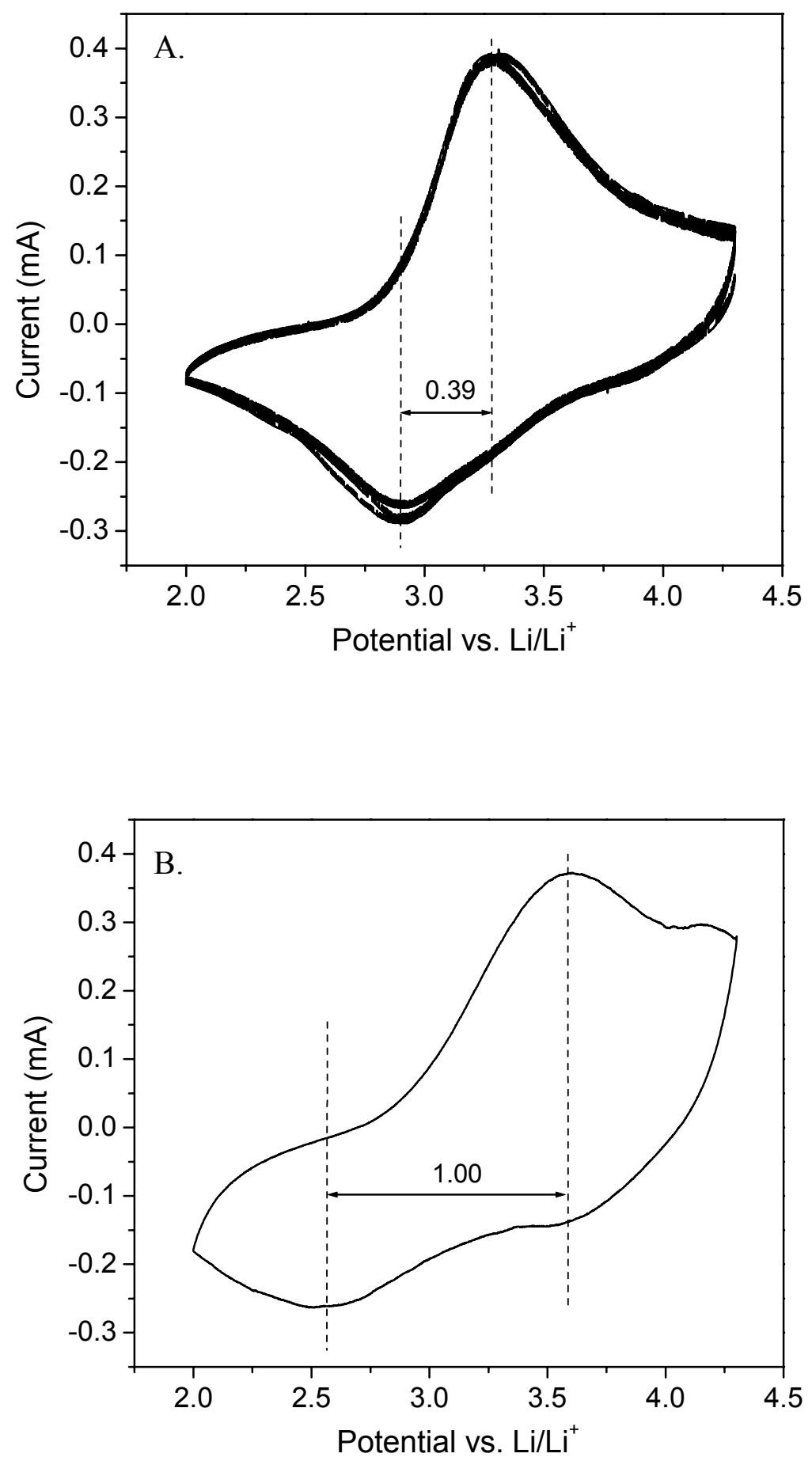
Figure 4.

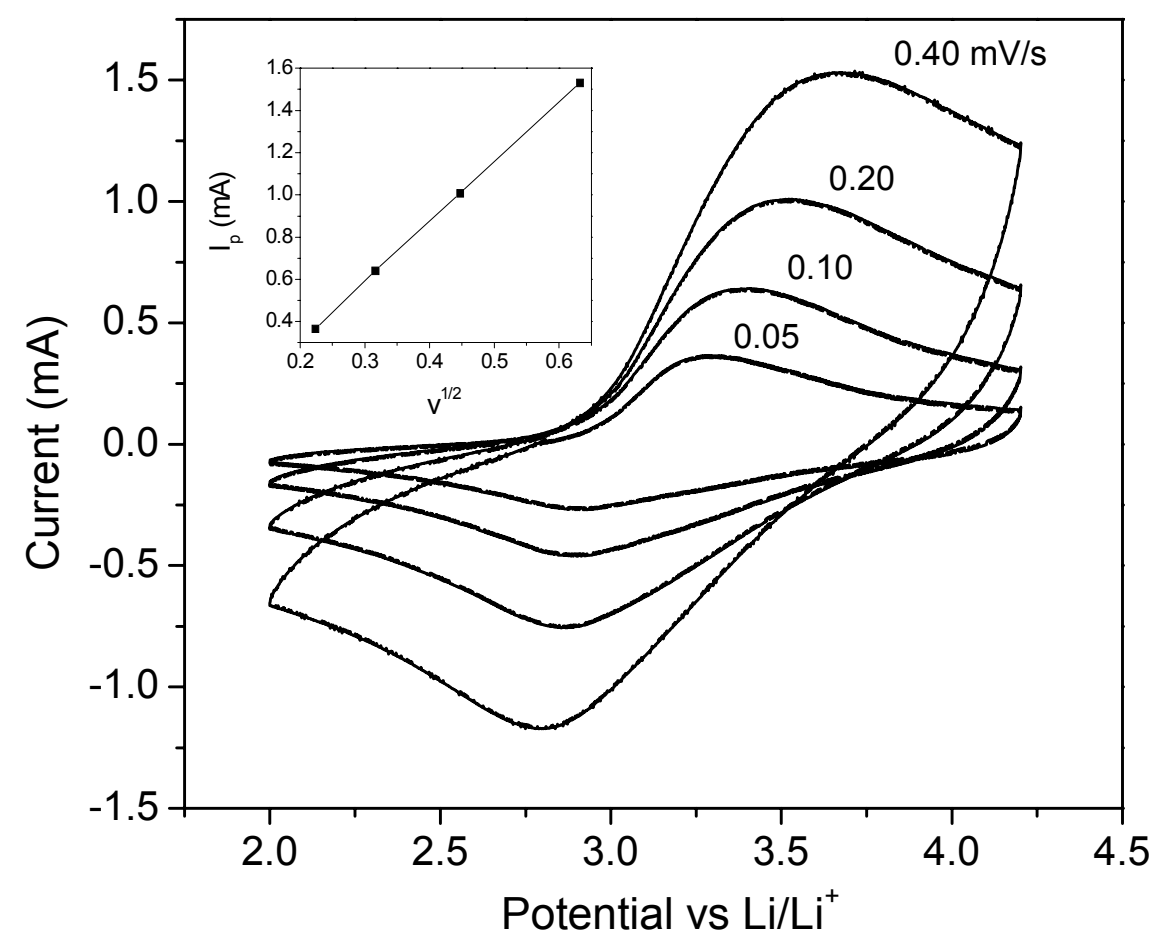


Figure 5.
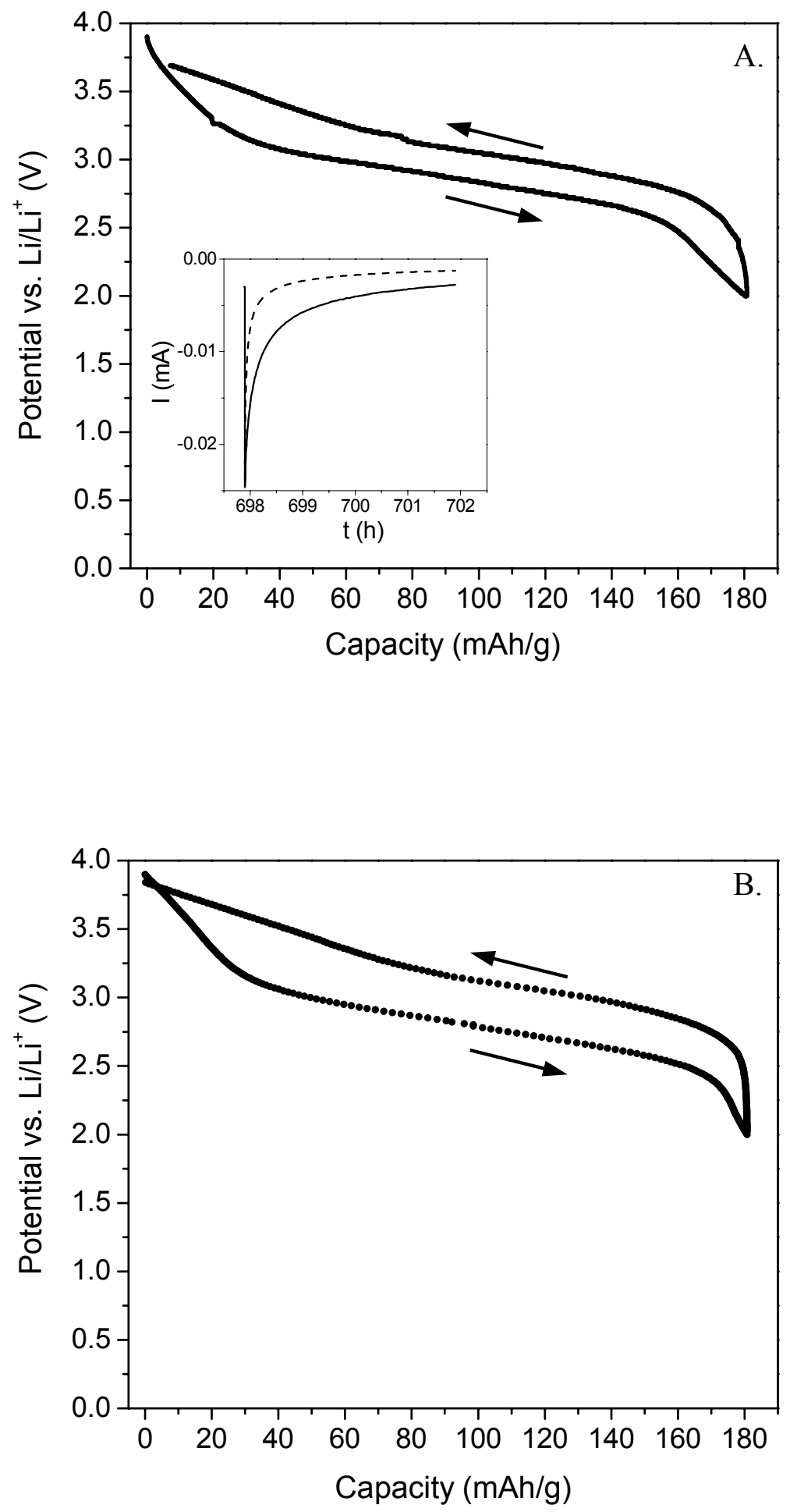